\title{
In Silico Docking Analysis and Admet Prediction of Thymoquinone Derivatives Against Ovarian Cancer
}

\author{
MAVARA AZMI', IMAM PASHA SYED ${ }^{2 *}$ and ANUPAMA KONERU ${ }^{3}$ \\ 1'Department of Pharmaceutical Chemistry, Sultan-ul-Uloom College of Pharmacy Mount Pleasant, \\ \#8-2-249, Road no. 3, Banjara hills, Hyderabad-500034, Telangana, India. \\ ${ }^{2}$ Department of Pharmaceutical quality Assurance, Sultan-ul-uloom College of Pharmacy Mount \\ Pleasant, \#8-2-249, Road no.3, Banjara hills, Hyderabad- 500034, Telangana, India. \\ ${ }^{3}$ Department of Pharmacology, Sultan-ul-uloom College of Pharmacy Mount Pleasant, \\ \#8-2-249, Road no.3, Banjara hills, Hyderabad- 500034, Telangana, India. \\ *Corresponding Author E-mail: imampharmaceuticalsciences@gmail.com, impazam @ gmail.com
}

http://dx.doi.org/10.13005/ojc/370130

(Received: August 20, 2020; Accepted: January 02, 2021)

\begin{abstract}
Thymoquinone, the active constituent of Nigella sativa has been reported to have various biological activities. Due to its significance, various analogues of it have been synthesized and reported for anti-cancer activity. In the present research, we have taken the analogs of thymoquinone and performed docking study with an objective to find the binding pattern of all the molecules. Apart from this, pharmacokinetic parameters were predicted along with their toxicological parameters. From the results, the molecule Thy09 was found to have the optimized structure and further modification on this could lead to more potent compounds.
\end{abstract}

Keywords: Thymoquinone, Nigella sativa, Analogs, Docking studies, Pharmacokinetic and Toxicological profile.

\section{INTRODUCTION}

Nature has produced various medicinal plants for treatment of various ailments and among those is the plant Nigella sativa ${ }^{1}$. It is a plant belonging to ranunculaceae family and is also known with various names (black caraway, black cumin, kalojeera, kalonji) ${ }^{2}$. It is known to be a miraculous plant as it possesses extraordinary activities such as analgesic ${ }^{3}$, anti-bacterial ${ }^{4}$, anti-viral ${ }^{5}$, anti-diabetic ${ }^{6}$, hepatoprotective ${ }^{7}$, etc. These activities are basically due to the presence of an active component called as "thymoquinone". This active component alone has been reported to produce excellent anti-oxidant as well as anti-inflammatory property ${ }^{9,10}$. Other than these, reports concerning its anti-cancer activity were also reported ${ }^{11-13}$. Other important effects shown by thymoquinone were anti-diabetic ${ }^{14}$, hepatoprotective ${ }^{15}$, anti-viral ${ }^{16}$ as well as its use in treating autoimmune disorders such as vitiligo ${ }^{17}$. Considering the significance of thymoquinone and its structure, various derivatives of it were synthesized earlier and

This is an Open Access article licensed under a Creative Commons license: Attribution 4.0 International (CC- BY). Published by Oriental Scientific Publishing Company @ 2018

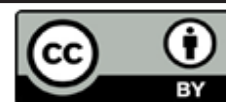


evaluated for their biological activity ${ }^{18,19}$. It was shown to produce promising results against ovarian cancer and also as anti-malarial activity ${ }^{18}$. To understand the structural activity relationship and to identify the pharmacophore, one has to adhere to computational techniques which shortens the time to determine the pharmacophore ${ }^{20}$. Hence, in this research work, we have taken the thymoquinone analogs having action against ovarian cancer and performed docking studies to understand the binding pattern of all the derivatives. Furthermore, we have also predicted various pharmacokinetic parameters and also its<smiles>CC1=CC(=O)C(C(C)C)=CC1=O</smiles><smiles>C=NC1=C(C)C(=O)C=C(C(C)C)C1=O</smiles><smiles>CCNC1=C(C)C(=O)C(C(C)C)=CC1=O</smiles><smiles>CC1=C(N)C(=O)C(C(C)C)=CC1=O</smiles><smiles>CC1=CC(=O)C(N(C)C)=CC1=O</smiles><smiles>CC1=CC(=O)C=C(N(C)C)C1=O</smiles><smiles>CC1=CC(=O)C(Nc2ccc(F)cc2)=C(C)C1=O</smiles><smiles>CC1=C(Cl)C(=O)C(C(C)(C)C)=C(Cl)C1=O</smiles><smiles>CC(C)(C)C1=CC(=O)C=CC1=O</smiles><smiles>CC(C)(C)C1=CC(=O)C(C(C)(C)C)=CC1=O</smiles><smiles>[B]C1=C(C(C)C)C(=O)C(Br)=C(C)C1=O</smiles><smiles>CC1=CC(=O)C=C(C)C1=O</smiles>

toxicology profile to screen the compounds with high risk which can give insight of the optimized molecule with greater activity.

\section{MATERIALS AND METHODS}

Selection of thymoquinone analogues for study Literature survey reveals various analogs of thymoquinones from which, we have shortlisted the molecules which have got $\mathrm{IC}_{50}$ values against cancer (particularly ovarian cancer) ${ }^{18}$. The list of molecules taken for study were sketched in chemDraw (v14) can be seen in Figure 1.
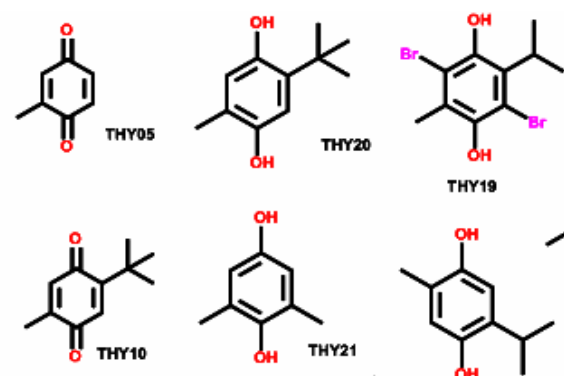<smiles>Cc1cc(O)cc(C)c1O</smiles><smiles>C=C/C(O)=C(/C)C(C)C</smiles><smiles>CC(C)(C)C1=CC(=O)C=C(C(C)(C)C)C1=O</smiles><smiles>CC(C)(C)C(C)(C)C1=CC(=O)C(C(C)(C)C(C)(C)C)=CC1=O</smiles>

Fig. 1. Thymoquinone analogs taken for study

\section{Calculation of physiological parameters}

The physiological parameters of the molecules include molecular weight, h-bond donor, acceptor, its partition co-efficient (LogP), molar refractivity and total polar surface area (TPSA). In order to calculate these values, the molecules were sketched in chembiodraw (version 14, developed by perkinelmer) and saved in ".Sdf" format. These saved structures were used to calculate the drug likeness from freely available online swissadme tool ${ }^{21}$.

\section{Prediction of pharmacokinetic parameters}

Drugs are said to be good when it is easily absorbed, distributed, metabolized and excreted from the human body. In order to screen the molecules, In-silico methods are majorly adopted wherein the pharmacokinetic parameters are predicted based on the molecular structure by comparing with the large number of molecules in the database and by similarity searching. SwissADME tools does that function and gives the details of the drug's pharmacokinetic profile which include GI absorption, BBB permeability, P-GP substrate, cyp450 inhibition and Log $\mathrm{K}_{\mathrm{p}}$ (skin permeation). Therefore, all the molecules in study were used to predict their pharmacokinetic parameters.

\section{Obtaining of protein crystal structure}

The thymoquinone analogs were shown to have anti-cancer activity (ovarian cancer in particular). The protein structure corresponding to the said activity was found to be ISAO from the literature. Therefore, the protein molecule (PDB ID: 1SA0) which is a complex of tubulin with colchicine was downloaded from protein databank (www. rcsb.org) with the resolution of 3.58 å. The ligand was manually removed and the active site was observed from pdbsum website (http://www.ebi. ac.uk) and the co-ordinates for generating grid box was observed from protein viewer $(x=123.324$, $Y=97.286$ And $z=6.838$ ).

\section{Preparation of ligands}

As the molecules are new and cannot be available in the database, these were sketched 
in ChemBio3d ultra version 14.0 Software and minimized using minimize structure option of calculate tool from the toolbar. The molecules after minimizing were saved in ".Mol2" format.

\section{Docking}

To perform the docking study of thymoquinone analogs, autodock version 4.2.6 Was used. The ligand as well as protein files were converted to "pdbqt" format and proceeded further for autogrid and autodock respectively. It was then analyzed for the results.

\section{Toxicological parameters prediction}

Most of the molecules, despite having a desired pharmacological activity possess certain side effects and also sometimes my act as a toxic substance resulting in various reactions within the body. Few online tools are available which can predict the toxic properties of compounds based on the similarity of the structure from the databases. Hence, to accomplish this, we have used swissADME tool which is available for free to use to obtain the toxicological parameters which are discussed in results and discussion.

\section{REDULTS AND DISCUSSION}

\section{Molecules selection and physiological properties}

From the literature, twenty-two molecules were selected including thymoquinone which were reported to have $\mathrm{IC}_{50}$ value against ovcar-8 (ovarian cancer cell line). These molecules were sketched and saved in "sdf" format and checked for physiological parameters and screen out the compounds which does not obey lipinski rule of five (mol. Wt $\leq 500$, $\log \mathrm{P} \leq 5$, hd $\leq 5$, ha $\leq 10$ ). All the molecules were shown to have obeyed the lipinski rule except thy ${ }^{17}$ as its $\log p$ value was observed to be greater than 5. All the physiological parameters are shown in the following Table 1. From the values obtained, it can be said that all these molecules can be administered orally except THY17 as its $I_{50}$ values is also the highest (Table 4). All the molecules were small with lipophilic in nature as they obey the lipinski $\mathrm{RO}$, hence possess high absorption.

Table 1: Physiological parameters of thymoquinones

\begin{tabular}{|c|c|c|c|c|c|c|c|c|}
\hline Compound name & Molecular formula & Mol Weight (g/mol) & $\mathrm{HA}$ & $\mathrm{HD}$ & TPSA & MR & $\log P$ & Drug-likeness \\
\hline THY01 & $\mathrm{C}_{10} \mathrm{H}_{12} \mathrm{O}_{2}$ & 164.20 & 2 & 0 & 34.14 & 47.52 & 1.018 & -1.1996 \\
\hline THY02 & $\mathrm{C}_{11} \mathrm{H}_{15} \mathrm{NO}_{2}$ & 193.24 & 3 & 1 & 46.17 & 55.13 & 1.502 & 2.7825 \\
\hline THY03 & $\mathrm{C}_{12} \mathrm{H}_{17} \mathrm{NO}_{2}$ & 207.27 & 3 & 1 & 46.17 & 59.94 & 1.925 & 2.5661 \\
\hline THY04 & $\mathrm{C}_{10} \mathrm{H}_{13} \mathrm{NO}_{2}^{2}$ & 179.22 & 3 & 0 & 60.16 & 50.23 & 1.039 & -0.022 \\
\hline THY05 & $\mathrm{C}_{7} \mathrm{H}_{6} \mathrm{O}_{2}$ & 122.12 & 2 & 0 & 34.14 & 33.10 & -0.047 & -0.6921 \\
\hline THY06 & $\mathrm{C}_{9} \mathrm{H}_{11} \mathrm{NO}_{2}$ & 165.19 & 3 & 0 & 37.38 & 45.61 & 0.487 & 1.4535 \\
\hline THY07 & $\mathrm{C}_{9} \mathrm{H}_{11} \mathrm{NO}_{2}$ & 165.19 & 3 & 0 & 37.38 & 45.61 & 0.487 & 1.8235 \\
\hline THY08 & $\mathrm{C}_{13} \mathrm{H}_{10} \mathrm{FNO}_{2}$ & 231.22 & 3 & 1 & 46.17 & 61.89 & 1.154 & -1.4514 \\
\hline THY09 & $\mathrm{C}_{10} \mathrm{H}_{10} \mathrm{Br}_{2} \mathrm{O}_{2}$ & 321.99 & 2 & 0 & 34.14 & 63.26 & 2.608 & -7.9858 \\
\hline THY10 & $\mathrm{C}_{11} \mathrm{H}_{14} \mathrm{O}_{2}$ & 178.23 & 2 & 0 & 34.14 & 52.07 & 1.514 & -7.1574 \\
\hline THY11 & $\mathrm{C}_{11} \mathrm{H}_{12} \mathrm{Cl}_{2} \mathrm{O}_{2}$ & 247.12 & 2 & 0 & 34.14 & 61.66 & 2.668 & -5.7822 \\
\hline THY12 & $\mathrm{C}_{10} \mathrm{H}_{12} \mathrm{O}_{2}^{2}$ & 164.20 & 2 & 0 & 34.14 & 47.26 & 1.333 & -4.2276 \\
\hline THY13 & $\mathrm{C}_{14} \mathrm{H}_{20} \mathrm{O}_{2}$ & 220.31 & 2 & 0 & 34.14 & 66.23 & 2.894 & -5.0241 \\
\hline THY14 & $\mathrm{C}_{8} \mathrm{H}_{8} \mathrm{O}_{2}$ & 136.15 & 2 & 0 & 34.14 & 37.91 & 0.134 & -1.0759 \\
\hline THY15 & $\mathrm{C}_{14} \mathrm{H}_{20} \mathrm{O}_{2}$ & 220.31 & 2 & 0 & 34.14 & 66.23 & 2.894 & -4.5682 \\
\hline THY16 & $\mathrm{C}_{16} \mathrm{H}_{24} \mathrm{O}_{2}$ & 248.36 & 2 & 0 & 34.14 & 75.84 & 4.032 & -0.1315 \\
\hline THY17 & $\mathrm{C}_{20} \mathrm{H}_{32} \mathrm{O}_{2}$ & 304.47 & 2 & 0 & 34.14 & 94.55 & 6.26 & -9.7535 \\
\hline THY18 & $\mathrm{C}_{10} \mathrm{H}_{14} \mathrm{O}_{2}$ & 166.22 & 2 & 2 & 40.46 & 50.03 & 1.984 & -2.3359 \\
\hline THY19 & $\mathrm{C}_{10} \mathrm{H}_{12} \mathrm{Br}_{2} \mathrm{O}_{2}$ & 324.01 & 2 & 2 & 40.46 & 65.43 & 3.49 & -4.1259 \\
\hline THY20 & $\mathrm{C}_{11} \mathrm{H}_{16} \mathrm{O}_{2}$ & 180.24 & 2 & 2 & 40.46 & 54.72 & 2.396 & -5.276 \\
\hline THY21 & $\mathrm{C}_{8} \mathrm{H}_{10} \mathrm{O}_{2}$ & 138.16 & 2 & 2 & 40.46 & 40.42 & 1.016 & .2 .315 \\
\hline THY22 & $\mathrm{C}_{7} \mathrm{H}_{8} \mathrm{O}_{2}$ & 124.14 & 2 & 2 & 40.46 & 35.45 & 0.835 & -2.315 \\
\hline
\end{tabular}

HA = Hydrogen bond acceptor; HB = Hydrogen bond donor; MR = Molar Refractivity; TPSA = Topological Polar Surface Area; Log $\mathrm{P}=$ Partition co-efficient $\left(\mathrm{P}_{\mathrm{o} / \mathrm{w}}\right)$

Pharmacokinetic parameters

Absorption profile of thymoquinone analogues

The drugs with good pharmacokinetic profile produce better results when administered. Once a drug it administered; it needs to undergo adme process ${ }^{22}$. Hence, we have predicted the 
pharmacokinetic profile of the molecules in our study. As per the Fig. 1 and Table 2, the drug molecules were found to be lipophilic due to presence of alkyl chains and furthermore, the molecules obey lipinski rule of 5 . Therefore, the molecules can be considered to have greater $\mathrm{Gl}$ absorption and have permeability to blood brain barrier (BBB). The results of pharmacokinetic profile are shown in Table 2.

Table 2: Absorption and distribution of thymoquinone analogs

\begin{tabular}{|c|c|c|c|c|c|c|c|c|c|c|c|}
\hline & THY01 & THY02 & THY03 & THY04 & THY05 & THY06 & THY07 & THY08 & THY09 & THY10 & THY11 \\
\hline Gl Absorption & High & High & High & High & High & High & High & High & High & High & High \\
\hline BBB permeability & Yes & Yes & Yes & Yes & Yes & Yes & Yes & Yes & Yes & Yes & Yes \\
\hline P-GP Substrate & No & No & No & No & No & No & No & No & No & No & No \\
\hline \multirow[t]{2}{*}{$\log K_{p}$} & -5.74 & -6.25 & -6.07 & -6.63 & -6.53 & -6.55 & -6.78 & -6.11 & -5.89 & -5.55 & -5.14 \\
\hline & THY12 & THY13 & THY14 & THY15 & THY16 & THY17 & THY18 & THY19 & THY20 & THY21 & THY22 \\
\hline Gl Absorption & High & High & High & High & High & High & High & High & High & High & High \\
\hline BBB permeability & Yes & Yes & Yes & Yes & Yes & Yes & Yes & Yes & Yes & Yes & Yes \\
\hline P-GP Substrate & No & No & No & No & No & No & No & No & No & No & No \\
\hline $\log K_{p}$ & -5.86 & -4.51 & -6.26 & -4.51 & -4.63 & -4.06 & -5.23 & -5.38 & -5.52 & -6.43 & -6.41 \\
\hline
\end{tabular}

Note: $\log \mathrm{K}_{\mathrm{p}}=$ Skin Permeation

$\mathrm{P}$-glucoprotein is a cell membrane protein that binds to drug molecules decreasing the pharmacokinetic profiles of those drugs. If drugs bind to $p$-gp, it pumps back the drug into the lumen which then undergoes metabolism in the liver followed by excretion through proximal tubule of kidney. All the molecules which were predicted for $\mathrm{p}$-gp substrate, show no binding as can be seen in Table 3, therefore, possess good absorption and greater efficacy.

Table 3: Metabolism of thymoquinone analogs

\begin{tabular}{|c|c|c|c|c|c|}
\hline \multirow{2}{*}{$\begin{array}{l}\text { Compound } \\
\text { name }\end{array}$} & \multicolumn{5}{|c|}{ CYP450 inhibition } \\
\hline & CYP1A2 & CYP2C19 & CYP2C9 & CYP2D6 & CYP3A4 \\
\hline THY01 & No & No & No & No & No \\
\hline THY02 & Yes & No & No & No & No \\
\hline THY03 & Yes & No & No & No & No \\
\hline THY04 & No & No & No & No & No \\
\hline THY05 & No & No & No & No & No \\
\hline THY06 & No & No & No & No & No \\
\hline THY07 & No & No & No & No & No \\
\hline THY08 & Yes & Yes & No & No & No \\
\hline THY09 & Yes & Yes & No & No & No \\
\hline THY10 & No & No & No & No & No \\
\hline THY11 & Yes & No & Yes & No & No \\
\hline THY12 & No & No & No & No & No \\
\hline THY13 & Yes & No & Yes & No & No \\
\hline THY14 & No & No & No & No & No \\
\hline THY15 & Yes & No & Yes & No & No \\
\hline THY16 & Yes & Yes & No & No & No \\
\hline THY17 & Yes & No & No & No & No \\
\hline THY18 & Yes & No & No & No & No \\
\hline THY19 & Yes & No & Yes & Yes & No \\
\hline THY20 & Yes & No & No & No & No \\
\hline THY21 & No & No & No & No & Yes \\
\hline THY22 & No & No & No & No & Yes \\
\hline
\end{tabular}

\section{Metabolism profile of thymoquinone analogs}

Most of the drugs undergoes metabolism in liver in presence of cytochrome $\mathrm{P} 450$ which contains various groups of enzymes. The main function of this is to metabolize the drugs to easily excretable forms. The majorly contributing groups for metabolism include CYP1A2, CYP2C19, CYO2C9, CYP2D6 and CYP3A4. If the drugs not metabolized via these enzymes, it can be said that the drug has inhibitory effect on the CYP450 enzyme groups. Therefore, from adme prediction of the drugs, we have observed the drugs to have inhibitory effect against few of the groups of CYP450. For an instance, more drugs have shown inhibitory action against CYP1A2, while the others have very a smaller number of analogs showing inhibitory effect. This provides and insight that the molecules can be metabolized via CYP450 there by converting them to easily excretable forms. The complete metabolism profile of the drugs can be seen in Table 3.

\section{Docking analysis of thymoquinone analogs}

To understand the binding affinity of the analogues with the ovarian cancer protein, docking was performed with a tubulin protein (PDB ID:1SA0, 3.58å) obtained from protein data bank. Gasteiger charges were applied on the protein and docked by following genetic algorithm. Among all the molecules, three molecules were shown to have no interactions which are THY10, THY13 and THY15. The docking analysis results are shown in the following Table 4 and the graph can be seen in Figure 2. 


\section{BINDING ENERGIES OF THYMOQUINONE ANALOGS}

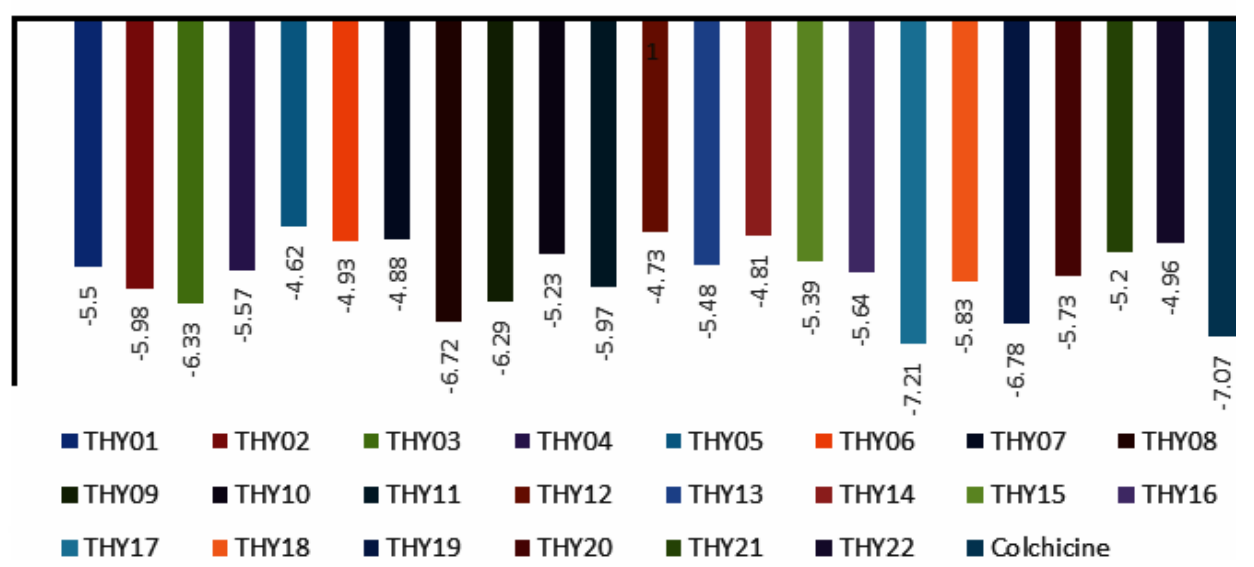

Fig. 2. Binding energies of Thymoquinone analogs

Table 4: Docking results of thymoqinone analogs

\begin{tabular}{|c|c|c|c|c|c|}
\hline Comp name & $\begin{array}{c}\text { IC50 } \\
\text { OVCAR-8 }\end{array}$ & $\begin{array}{c}\text { Binding } \\
\text { energy }(\Delta \mathrm{G})\end{array}$ & $\begin{array}{c}\text { Inhibitory } \\
\text { constant (Ki) }\end{array}$ & RMSD & Binding residues with bond length $(\AA)$ \\
\hline THY01 & 11.6 & -5.5 & $93.32 \mu \mathrm{M}$ & 161.39 & ASN206-1.916 \\
\hline THY02 & 12.9 & -5.98 & $41.19 \mu \mathrm{M}$ & 161.42 & ASN228-1.992 with NH. \\
\hline THY03 & 16 & -6.33 & $22.93 \mu \mathrm{M}$ & 161.27 & ASN206-1.992; ASN228-1.872 \\
\hline THY04 & 35.1 & -5.57 & $82.11 \mu \mathrm{M}$ & 161.84 & ASN206-2.141 \\
\hline THY05 & 13.4 & -4.62 & $409.55 \mu \mathrm{M}$ & 162.8 & ASN206-1.694, ASN228-1.975 \\
\hline THY06 & 5.6 & -4.93 & $244.68 \mu \mathrm{M}$ & 161.2 & ASN206-2.211 with $(=0)$ \\
\hline THY07 & 35.6 & -4.88 & $266.88 \mu \mathrm{M}$ & 161.14 & ASN206-1.974 with $(=0)$ \\
\hline THY08 & 32 & -6.72 & $11.81 \mu \mathrm{Ms}$ & 159.54 & ASN206-2.186, 1.748 \\
\hline THY09 & 3.6 & -6.29 & $24.54 \mu \mathrm{M}$ & 160.79 & ASN206-2.203 \\
\hline THY10 & 13.5 & -5.23 & $146.16 \mu \mathrm{M}$ & 160.86 & No interactions \\
\hline THY11 & 6 & -5.97 & $41.92 \mu \mathrm{M}$ & 160.78 & ASN206-2.172 \\
\hline THY12 & 10 & -4.73 & $338.56 \mu \mathrm{M}$ & 161.18 & GLM11-2.129 \\
\hline THY13 & 51.2 & -5.48 & $95.39 \mu \mathrm{M}$ & 159.78 & No interactions \\
\hline THY14 & 5.2 & -4.81 & $298.7 \mu \mathrm{M}$ & 160.85 & ASN228-1.954 \\
\hline THY15 & 37.4 & -5.39 & $112.09 \mu \mathrm{M}$ & 159.82 & No interactions \\
\hline THY16 & 54.2 & -5.64 & $74.04 \mu \mathrm{M}$ & 159.11 & ASN206-1.96 \\
\hline THY17 & 56.5 & -7.21 & $5.2 \mu \mathrm{M}$ & 154.93 & ALA12-2.034 \\
\hline THY18 & 8.9 & -5.83 & $53.19 \mu \mathrm{M}$ & 161.45 & ASN206-2.074, 2.111; GLN15-2.199 \\
\hline THY19 & 11.6 & -6.78 & $10.7 \mu \mathrm{M}$ & 160.17 & ASN206-2.027; GLN15-2.166; GLN11-2.05 \\
\hline THY20 & 12.2 & -5.73 & $46.4 \mu \mathrm{M}$ & 160.44 & GLN15-2.124; GLN11-2.194; ASM206- 2.22, 2.027 \\
\hline THY21 & 8.3 & -5.2 & $154.95 \mu \mathrm{M}$ & 159.64 & GLY142-1.027; ILE171-1.929; SER178-1.792 \\
\hline THY22 & 6.2 & -4.96 & $233.28 \mu \mathrm{M}$ & 161.54 & GLN15-2.02; ASN206-2.091, 2.143 \\
\hline Colchicine & & -7.07 & $6.63 \mu \mathrm{M}$ & 156.02 & SER140-1.939 \\
\hline
\end{tabular}

Among the set of twenty-two molecules, compounds with better pIC $_{50}$ values were observed to be THY06, THY09, THY11, THY12, THY14, THY21 and THY22 with THY09 being the most active. From compounds THY06, THY09 and THY11, it can be deduced that the presence of electronegative atoms on the aromatic ring produces more activity. For instance, presence of a tertiary amine at $5^{\text {th }}$ position of THY06 instead of isopropyl group as in case of THY01 shows more potency which can be as a result of lone pair of electrons present on the nitrogen that is donating its electrons resulting in more electronegativity at the $4^{\text {th }}$ keto group there by forming a better bonding with hydrogen of ASN206 residue (bond length:2.203) While presence of same dimethyl group at position $6^{\text {th }}$ show reduced activity. It can be conferred that, substituted heteroatoms at position 5 if present shows more potency than the parent molecule (THY01). Introduction of halogens to the parent molecule (THY01) is observed to have 
greater activity than THY06 as can be observed in the docking result of THY09 and THY11. However, bromo substitutions at position 3 and 6 has more potency than chloro-substitution. Therefore, presence of low electronegative halogens shows better action. The $4^{\text {th }}$ position keto group is essential as it has shown binding with the active site residues of the 1 SAO protein. The docking images of THY06, THY09 and THY11 can be seen in the Figure $3(\mathrm{a}-\mathrm{c})$.

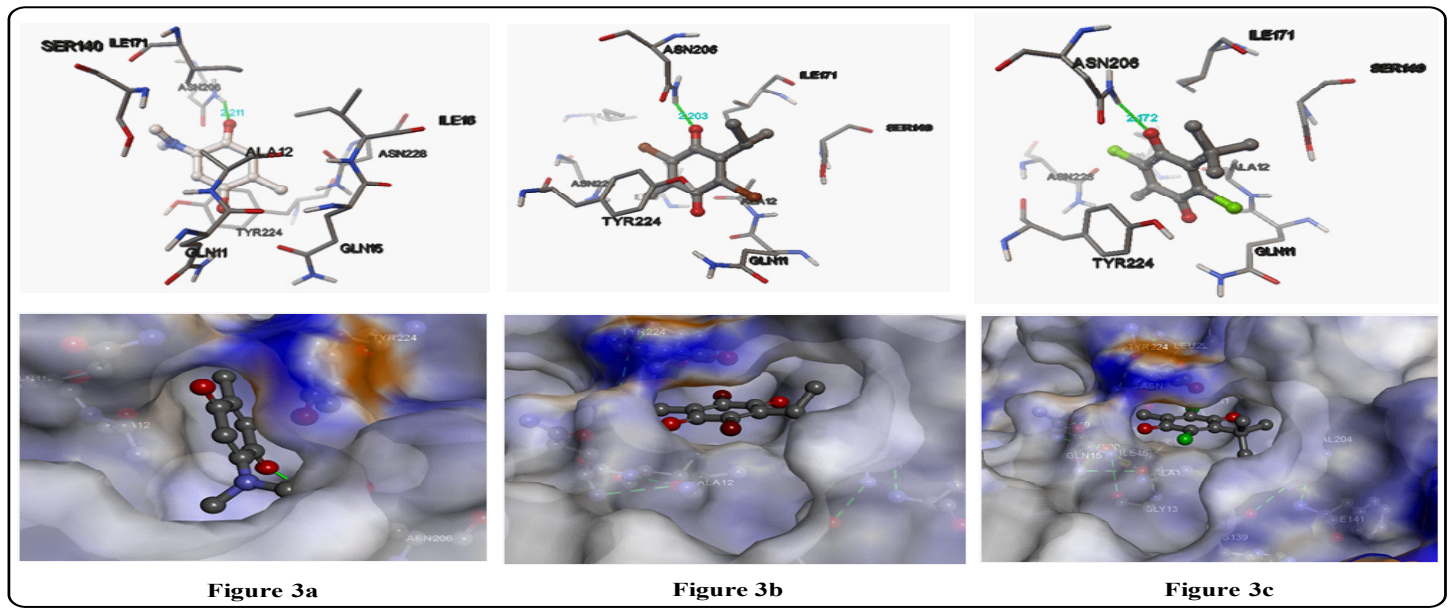

Fig. 3: a) Docking images of Thy06 b) Docking images of Thy09 c) Docking images of Thy11

Similarly, in case of THY21 and THY22, which are the reduced forms of THY14 and THY05 respectively, all the four compounds have good activity except the fact that, THY05 shows binding with ASN206 and ASN228 with the $1^{\text {st }}$ and $4^{\text {th }}$ position ketone group while THY22 shows binding with GLN15 and ASN206 with the hydroxyl groups as can be observed in Fig. $4 a$ and $4 \mathrm{~b}$. Furthermore, compound THY21 which is the reduced form of THY14 shows binding with GLY142, ILE171 and SER178 while THY14 shows binding with ASN228 as can be seen from Fig. $4 \mathrm{c}$ and $4 \mathrm{~d}$ respectively. However, none of the compounds show the activity as potent as colchicine either in terms of their $\mathrm{IC}_{50}$ or in terms of binding affinity but shows closer value. Since THY14 is the most active compound, it can be inferred that retaining $4^{\text {th }}$ keto group and reducing the $1^{\text {st }}$ keto group may provide an insight in developing drugs which can shows more binding with the residues of the active site and as well possess good activity against cancer.

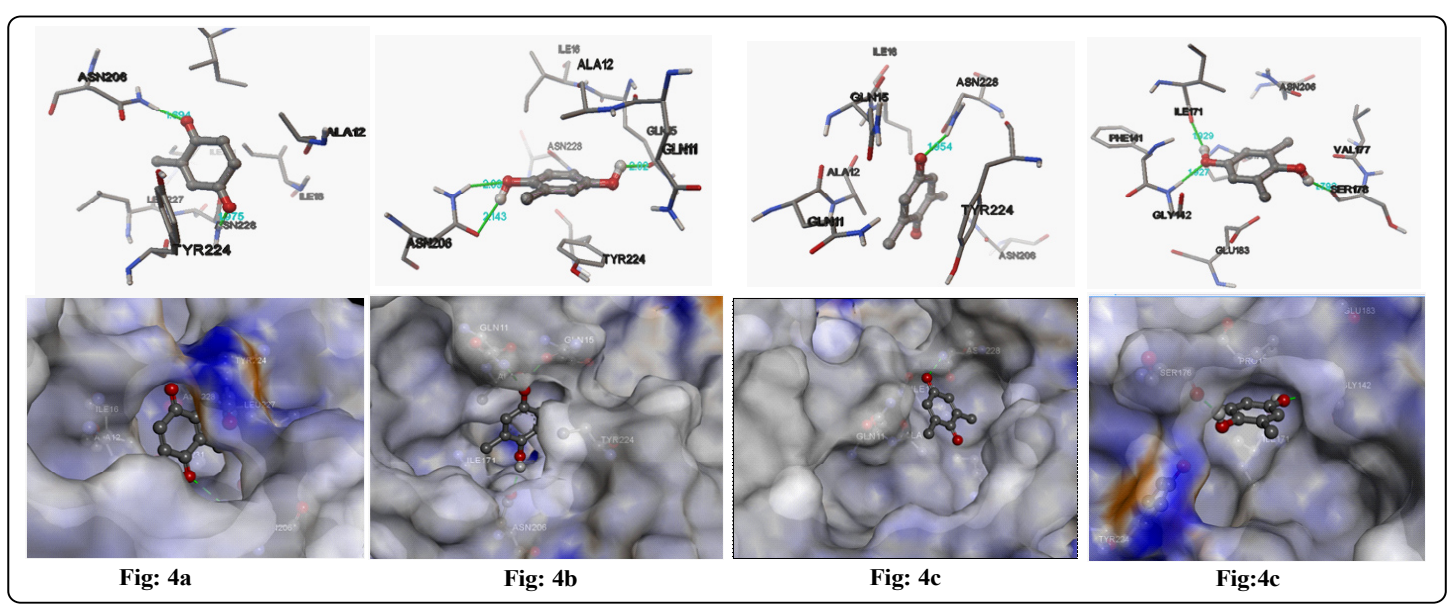

Fig. 4a. (Docking image of Thy05); 4b (Docking image of Thy22); 4c (Docking image of Thy14) and $4 d$ (Docking image of Thy21) 
Inhibitory constant is the term used to describe the potency of the drug. It is the lowest concentration at which the drug shows inhibitory effect. Autodock provides inhibitory constant values based on the its binding to the protein active site. Lower the ki value, potent will be its effect theoretically in case of in-silico studies. From the inhibitory constant values obtained as shown in Table 5 , the compound which is most active (THY09) gives $24.54 \mu \mathrm{m}$ followed by THY11 with $41.92 \mu \mathrm{m}$ which is four to six times greater than colchicine while the other molecules show higher ki values. Fig. 5 depicts the inhibitory constant values showing their Ki values.

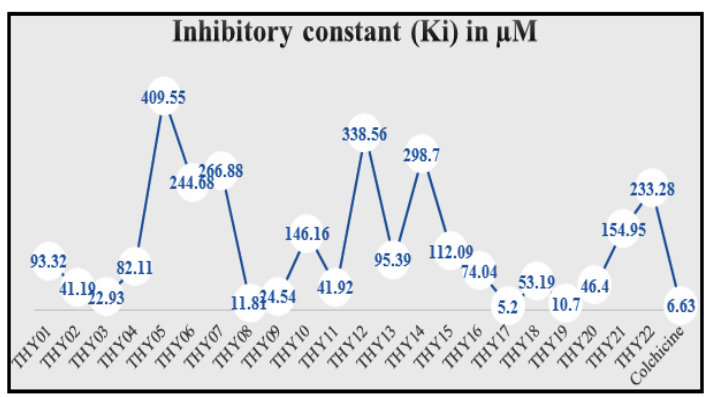

Fig. 10. Inhibitory constant values of Thymoquinone analogs

\section{Toxicological parameters prediction}

To obtain toxicology parameters of the compounds, we have used swissadme tool, where in, it predicts the toxic effects of the molecules based on its structure either to be mutagenic and tumorigenic. It also predicts if the molecules possess any effect on the reproductive system of human beings. From the results as can be seen in Table 5, most of the molecules show no tumorigenic property except THY21 and THY22 while THY20 and THY21 has shown to produce some effect on the reproductive system. Hence, the molecular properties of THY21 and THY22 are to be neglected from considering to be a part of scaffold.

On the other hand, THYO9 being the most active compound among the set of molecules shows none of the considered toxic properties, while molecules THY06, THY11 and THY12 shown to possess high mutagenic property. Therefore, THY09 can be considered as the optimized thymoquinone analogs based on which various modifications can be performed either by increasing the side chain or introducing hetero substitution on the $5^{\text {th }}$ position, retaining $4^{\text {th }}$ keto group and reducing $1^{\text {st }}$ keto group can help in developing more potent molecules.

Table 5: toxic parameters of thymoquinone analogs

\begin{tabular}{|c|c|c|c|c|c|c|c|}
\hline Mol name & Mutagenic & Tumorigenic & Reproductive effect & Mol name & Mutagenic & Tumorigenic & Reproductive effect \\
\hline THY01 & High & None & None & THY12 & High & None & None \\
\hline THY02 & None & None & None & THY13 & High & None & None \\
\hline THY03 & None & None & None & THY14 & High & None & None \\
\hline THY04 & None & None & None & THY15 & None & None & None \\
\hline THY05 & High & None & None & THY16 & Low & None & None \\
\hline THY06 & Low & None & None & THY17 & Low & None & None \\
\hline THY07 & None & None & None & THY18 & High & Low & None \\
\hline THY08 & Low & None & None & THY19 & None & None & None \\
\hline THY09 & None & None & None & THY20 & High & High & High \\
\hline THY10 & Low & None & None & THY21 & None & None & High \\
\hline THY11 & High & None & None & THY22 & None & High & None \\
\hline
\end{tabular}

\section{CONCLUSION}

Structure optimization was achieved by performing docking studies of various thymoquinone analogs as well as their pharmacokinetic and toxicological parameters were determined. From the results obtained, all the molecules obeyed lipinski rule except THY17. It was found that compound THY09 was most stable among all the molecules and was shown to have no toxic effects. Further dynamics studies are required to determine the stability of the binding complex. In future aspect, structural modifications of THY09 such as retaining of $4^{\text {th }}$ keto group and reduction of $1^{\text {st }}$ keto, addition of bulky hetero groups such as pyrazine or phenyl sulfur, etc., On $5^{\text {th }}$ position of the aromatic ring could lead to the compounds with greater potency.

\section{ACKNOWLEDGEMENT}

The authors are thankful to management \& principal of Sultan-UI-Uloom college of pharmacy for providing research facilities for this work.

\section{Conflict of interest}

The authors declare that they have no conflict of interest. 


\section{REFERENCES}

1. Majeed A.; Muhammad Z.; Ahmad H.; Hayat SS.; Inayat N.; Siyyar S. Acta ecologica sinica., 2020.

2. Sultana S.; Asif HM.; Akhtar N.; Iqbal a.; Nazar H.; Rehman Ru. J. Pharmacognosy phytother., 2015, 4(4), 103-6.

3. Ghannadi A.; Hajhashemi V.; Jafarabadi H. J. Med. Food., 2005, 8(4), 488-93.

4. Chaieb K.; Kouidhi B.; Jrah H.; Mahdouani K.; Bakhrouf A. BMC Complem Altern M., 2011, 11(1), 29.

5. Khan AU.; Tipu MY.; Shafee M, Khan NU.; Tariq MM.; Kiani MR.; Shah SI. Pak Vet J., 2018, 38, 434-7.

6. Benhaddou-Andaloussi A.; Martineau I, Vuong T.; Meddah B.; Madiraju P, Settaf A, Haddad PS. Evid-based Compl Alt., 2011, 2011.

7. Adam GO.; Rahman MM, Lee SJ.; Kim GB.; Kang HS.; Kim JS.; Kim SJ. Asian pac. J. Trop. Med., 2016, 9(3), 221-7.

8. Ali BH.; Blunden G. Phytother res., 2003, 17(4), 299-305.

9. Ismail M.; Al-Naqeep G.; Chan KW. Free radic. Biol. Med., 2010, 48(5), 664-72.

10. El Gazzar M.; El Mezayen R.; Marecki JC.; Nicolls MR.; Canastar A.; Dreskin SC. Int. Immunopharmacol., 2006, 6(7), 1135-42.

11. Woo CC.; Loo SY, Gee V.; YAP CW.; Sethi G.; Kumar AP.; Tan KH. Biochem. Pharmacol., 2011, 82(5), 464-75.

12. Attoub S.; Sperandio O.; Raza H.; Arafat K.; Al-Salam S.; Al Sultan MA.; Al Safi M,
Takahashi T.; Adem A. Fund clin pharmacol., 2013 , 27(5), 557-69.

13. Mahmoud YK.; Abdelrazek HM. Biomed pharmacother., 2019, 115, 108783.

14. Fararh KM.; Shimizu Y.; Shiina T.; Nikami H.; Ghanem MM., Takewaki T. Res. Vet. Sci., 2005, 79(3), 219-23.

15. Daba MH.; Abdel-Rahman MS. Toxicol. Lett., 1998, 95(1), 23-9.

16. Fröhlich T.; Reiter C.; Saeed ME.; Hutterer C, Hahn F.; Leidenberger M.; Friedrich O, Kappes B., Marschall M.; Efferth T.; Tsogoeva SB. Acs Med. Chem. Lett., 2017, 9(6), 534-9.

17. Ali Sa.; Meitei KV., J pharm pharmacol., 2011, 63(5), 741-6.

18. Johnson-Ajinwo OR.; Ullah I.; Mbye H.; Richardson A.; Horrocks P.; Li WW. Bioorg Med Chem Lett., 2018, 28(7), 1219-22.

19. Yusufi M.; Banerjee S.; Mohammad M, Khatal S.; Swamy KV.; Khan EM.; Aboukameel A, Sarkar FH.; Padhye S. Bioorg Med Chem Lett., 2013, 23(10), 3101-4.

20. Xiang M.; Cao Y.; Fan W.; Chen L.; Mo Y.; Comb. Chem. High Throughput Screen., 2012, 15(4), 328-37.

21. Swissadme: a free web tool to evaluate pharmacokinetics, drug-likeness and medicinal chemistry friendliness of small molecules. Sci. Rep., 2017, 7, 42717.

22. Benedetti MS.; Whomsley R.; Poggesi I, Cawello W.; Mathy FX.; Delporte ML, Papeleu P, Watelet JB.; Drug metab. Rev., 2009, 41(3), 344-90. 